\title{
DESENVOLVIMENTO DE UM CONJUNTO DE MODELAGEM DE ALTA RESOLUÇÃO PARA OS MÉTODOS ELETROMAGNÉTICOS INDUTIVOS
}

\author{
Alberto Leandro de Melo \\ Orientador: Dr. Om Prakash Verma (UFPA) \\ 91 p. - Dissertação (Mestrado) - Defesa 16.06.2004
}

RESUMO. A Modelagem Eletromagnética Analógica tem sido uma poderosa ferramenta no estudo das respostas eletromagnéticas de uma grande variedade das técnicas de levantamentos e de modelos geológicos. Nas aplicações de métodos eletromagnéticos nas investigações de contaminação no subsolo, recentemente em grande demanda, são obtidas anomalias muito baixas (da ordem de $0,01 \%$ do campo primário). Com o objetivo de estudar em laboratório os problemas de levantamentos eletromagnéticos para alvos de baixo número de indução, um conjunto de modelagem em escala reduzida de alta sensibilidade, foi projetado e construído. Este conjunto opera na faixa de frequêencia de $1 \mathrm{kHz}$ até $1 \mathrm{MHz}$ com excelente linearidade. 0 transdutor de transmissão gera suficiente densidade de fluxo magnético com corrente de até 3 Ap_p (pico a pico) circulando nele. 0 sistema de recepção, isto é, o conjunto de bobinas receptoras mais o pré-amplificador acoplado apresenta sensibilidade $3 \mathrm{~V} / \mathrm{A} / \mathrm{m}$ na freqüência de $10 \mathrm{kHz}$ com inclinação de $20 \mathrm{~dB} / \mathrm{dec}$ de frequêencia. A alta sensibilidade do sistema de recepção combinada com a boa capacidade de geração do sistema transmissor, permite alcançar a resolução de 0,025\% do campo primário. 0 conjunto dispõe ainda, de um sistema mecânico que permite posicionar o sistema de transdutores (transmissor e receptor) em posições arbitrárias com resolução de $1 \mathrm{~mm}$ e precisão de $0,05 \mathrm{~mm}$. A precisão no deslocamento linear do sistema de sonda numa linha de $1715 \mathrm{~mm}$ de comprimento é alcançada por meio de um motor de passo controlado por um microcontrolador, que é rigidamente acoplado a um fuso que converte o movimento angular do motor em movimento linear. Com este conjunto, é possível simular uma grande variedade de técnicas de levantamentos eletromagnéticos no formato Slingram, isto é, dipolo-dipolo. Além da boa resolução mecânica e boa resolução de medida eletromagnética do conjunto, todo o processo de controle e aquisição de dados é operacionalizado por meio de um computador mestre.

ABSTRACT. Electromagnetic analog modelling has been a powerful tool to study the electromagnetic response of a great varieties of survey techniques of different geological models. In the applications of The electromagnetic methods in the investigations of subsurface contaminations of in great demand recently, very low anomalies (of the order of $0.01 \% \mathrm{HP}_{\mathrm{P}}$ ) are obtained. To study in the laboratory the problems of the electromagnetic surveys of low induction number targets, an electromagnet reduced scale model set-up is designed and construed. This set-up operates in the frequency range off $1 \mathrm{kHz}$ to $1 \mathrm{MHz}$. The developed transmitting system generate a high magnetic flux density by passing a 3 Ap_p current in it. The receiving system, consist of a set coils and amplifier coupled in it, has a sensibility of $3 \mathrm{~V} / \mathrm{A} / \mathrm{m}$ at $10 \mathrm{kHz}$ with gradient of $20 \mathrm{~dB} / \mathrm{dec}$ frequency. The overall resolution of the set-up is $0.025 \% \mathrm{H}_{p}$, obtained due to the high sensitivity of the received system to generate primary field. The set-up also has a very precise mechanical system that permits locate the coils at any arbitrary position with a resolution of $1 \mathrm{~mm}$ and a precision $0.5 \mathrm{~mm}$. The Tx-Rx system cam be moved linearly with great precision up to $1715 \mathrm{~mm}$ in length, by rotating a spindle employing a microprocessor controlled stepper motor attached to it. With set-up, it is possible to simulate a great variety of electromagnetic survey techniques of Slingram systems, that is dipole-dipole configurations. Besides good mechanical and electromagnetic measurements resolutions; all the process of data acquisition and other operations in the set-up cam be controlled through a computer. 